UDC 577.21

\title{
Dependence of DNA persistence length on ionic conditions
}

\author{
M. I. Zarudnaya, A. L. Potyahaylo, D. M. Hovorun \\ Institute of Molecular Biology and Genetics, NAS of Ukraine \\ 150, Akademika Zabolotnoho Str., Kyiv, Ukraine, 03680 \\ m.i.zarudna@imbg.org.ua
}

DNA functioning requires both compaction for packaging into chromatin or virus particles and accessibility for looping to control gene expression. The persistence length $(\mathrm{P})$, closely related to the bending rigidity of double-stranded DNA, is highly relevant to these processes. In spite of numerous experimental and theoretical studies, a general agreement on the dependence of DNA persistence length on salt concentration has not been established and clear understanding about the fundamental forces responsible for DNA stiffness is still lacking. Here we describe a dependence of $P v s \mathrm{Na}^{+}$concentration based on several studies and discuss the impact of different factors, including DNA G- and A-tracts, on DNA persistence length.

Ke y w or d s: DNA, persistence length, effective diameter, G-tracts, A-tracts.

Nucleic acids are highly charged polyanionic molecules. The polyelectrolyte nature affects their stability, structure, reactivity and binding behavior [1]. Due to electrostatic repulsion between phosphate groups on the backbone, the excluded volume of DNA double helix significantly increases at low salt concentration. The persistence length $(P)$ and the effective diameter $\left(d_{e f}\right)$ are important characteristics of the excluded volume. The $d_{e f}$ is the diameter of an uncharged impenetrable polymer chain that mimics the conformational properties of actual electrically charged DNA [2]. The $d_{\text {ef }}$ corresponds to the distance of the closest approach between the helical axes of two nonadjacent DNA segments [3]. The de- pendence of the $d_{e f}$ on salt concentration has been experimentally determined from measurements of the osmotic pressure of DNA $[4,5]$, low-angle light scattering [6] and probability of DNA knotting $[3,7]$. These studies have shown that the DNA effective diameter can be several times greater than the geometric diameter. These findings are especially marked for supercoiled DNAs, where there are close contacts between portions of DNA chain [7].

The persistence length is a reflection of the chain contour length, over which the segment directions are correlated. $P$ of a virtual polymer chain comprising a string of $n$ segment vectors is the sum of the average projections of each

(C) 2017 M. I. Zarudnaya et al.; Published by the Institute of Molecular Biology and Genetics, NAS of Ukraine on behalf of Biopolymers and Cell. This is an Open Access article distributed under the terms of the Creative Commons Attribution License (http://creativecommons.org/licenses/by/4.0/), which permits unrestricted reuse, distribution, and reproduction in any medium, provided the original work is properly cited 
of the segment vectors on the first segment vector in the limit $n \rightarrow \infty$ [8]. The DNA persistence length, which is considered to be one half of the Kuhn statistical segment length, can be extracted from the mean-squared end-to-end distance, $<\mathrm{R}^{2}>$, of DNA fragments on the basis of the worm-like chain model $[8,9]$.

The DNA stiffness is highly relevant to the biological processes such as the DNA wrapping around histone protein to form nucleosomes, the packaging inside virus particles, the physical rearrangements of genomic DNA induced by transcription factors and others, i.e. DNA function requires both compression for packaging into chromatin or virus particle and accessibility for looping to control gene expression [9]. While there is a satisfactory agreement between different experimental dependences of DNA effective diameter on concentration of monovalent cations [2], dependences of DNA persistence length on $\mathrm{Na}^{+}$ concentration vary widely and have been unsatisfactory described by the theoretical dependences [10]. In this brief review we discuss impact of different factors on dependence of DNA persistence length on $\mathrm{Na}^{+}$concentration. In particular, we discuss structural features of DNA G- and A-tracts.

\section{Dependence of DNA persistence length on $\mathrm{Na}^{+}$concentration}

Dependences of DNA persistence length on $\mathrm{Na}^{+}$concentration reported by different experimental groups are presented in Fig. 1A. Compared to the similar combined data presented by Savelyev [10] we have changed somewhat a set of the literary sources. We added experimental data of Porschke [14] and have not used data of Cairney \& Harrington [20] and Maret \& Weill [21]. Cairney \& Harrington [20] obtained absolute values of DNA persistence length from the flow birefringence measurements based on assumed (constant) values of nucleotide optical anisotropy factors $\Delta \alpha$, which were chosen to facilitate comparison with the results of Kam et al. [11], Manning [16] and Rizzo \& Schellman [12]. The authors observed the most satisfactory agreement between their results and those of Rizzo \& Schellman [12] ( $\square$ in Fig. 1A). In case of other studies $[11,16]$ an agreement was close at intermediate salts $\left(10-100 \mathrm{mM} \mathrm{Na}^{+}\right)$but the authors' curves showed notably less dependences at both higher and lower salt concentrations. We have not included Cairney \& Harrington data [20] into combined graph (Fig. 1A) because the authors themselves consider the flow birefringence approach as a secondary method due to uncertainty in the $\Delta \alpha$.

Maret \& Weill data [21] were not included into the graph due to the uncertainties in the optical and diamagnetical anisotropy factors that resulted in a large error (about $\pm 30 \%$ ) in intrinsic persistence length. Besides, at low salt concentrations the experiments were carried out at $4{ }^{\circ} \mathrm{C}$ but DNA persistence length strongly depends on temperature [22]. In particular, when the temperature changes from $5{ }^{\circ} \mathrm{C}$ to $42{ }^{\circ} \mathrm{C}, P$ changes from $53 \mathrm{~nm}$ to $44 \mathrm{~nm}$. Experimental data presented in Fig. 1A were obtained at room temperature.

Despite the large scattering of the points in Fig. 1A a definite trend in $P$ variation with increasing salt concentration is observed. This trend is approximately illustrated by a solid curve, which is similar in shape to that presented by Savelyev [10], who has studied dependence of DNA persistence length on salt 


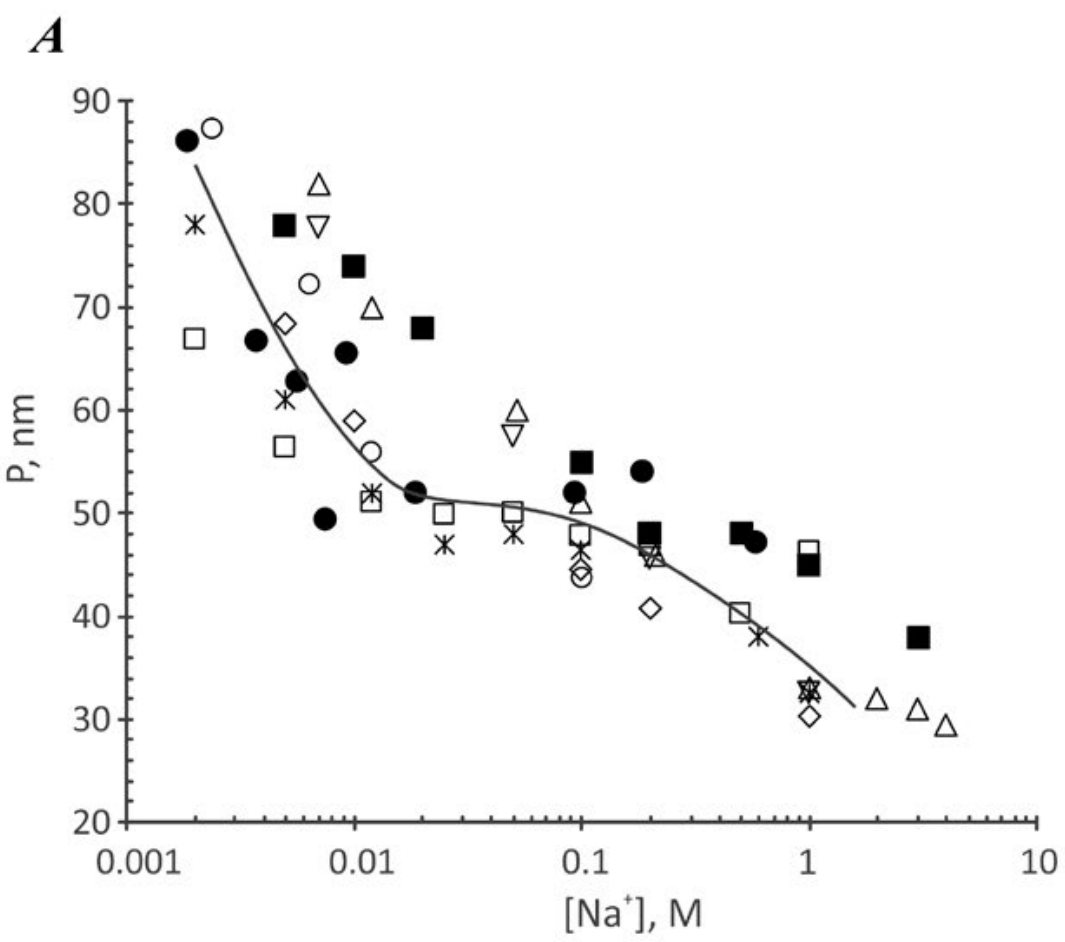

B

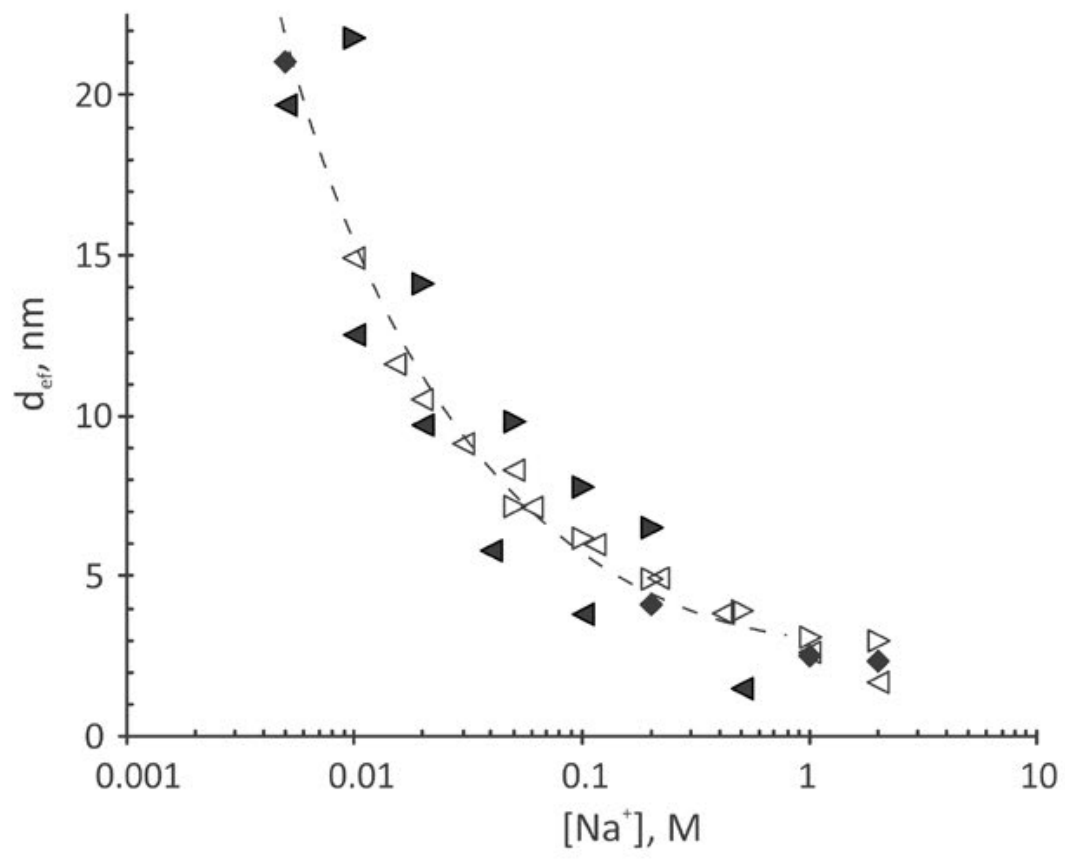

Fig. 1. $A$ - dependences of DNA persistence length on $\mathrm{Na}^{+}$concentration. Data are based on laser light scattering of Col E1 DNA [11] $(\diamond)$, flow dichroism of T7 DNA [12] ( $\square$ ), Rayleigh light scattering of T7 DNA (ם) [13], electrooptical measurements of DNA fragments [14] (O), using of force-measuring laser tweezers to determine the elastic properties of $\lambda$ DNA [15] ( ), and molecular dynamic simulations of a 150 base-pair DNA segment [10] (*). Additionally, theoretical corrections $[16](\triangle)$ and [17] $(\nabla)$ to Borochov et al. data [18] on laser light scattering of Col E1 DNA are shown. $B-$ dependences of DNA effective diameter on $\mathrm{Na}^{+}$concentration. Data are based on the equilibrium distribution of DNA fragments in the ultracentrifuge [4] $(\diamond)$, measurements of Col E1 DNA osmotic pressure [5] ( ), probability of knotting of DNA chains during a random cyclization $[7,3](\triangleleft, \triangleright)$, and light scattering of DNA fragments (calculated by Vologodskii \& Cozzarelli [2] from Nicolai \& Mandel data [6] (4)). The dashed line corresponds to the theoretical calculations [19]. Adapted from Vologodskii \& Cozzarelli [2]. 
concentration by means of molecular dynamics simulations with utilization of a chemically accurate coarse-grained model for double-stranded DNA with explicit mobile ions [23]. Since DNA persistence lengths generated by this method were systematically larger than the respective experimental values, the authors uniformly rescale MD simulation results by a factor of $\sim 0.7$, that led to nearly exact agreement with the experimental data taken from Hagerman's study [24] and other works [12, 15]. Hagerman [24] investigated the dependence of pBR322 DNA persistence length on salt concentration by a transient electric birefringence method at very low $\mathrm{NaCl}$ concentration (0.1-4.0 mM). In particular, he obtained the values of $\sim 180,60$ and $50 \mathrm{~nm}$ for $P$ in $0.1,2.0$ and $4.0 \mathrm{mM} \mathrm{Na}^{+}$, respectively. Thus, the $P$ value increases more than 3 times with a decrease in $\mathrm{Na}^{+}$concentration in this concentration interval.

It seems that a curve with a plateau-like region in the middle part, presented by Savelyev ( $*,[10])$, describes satisfactory the experimental data over a wide range of $\mathrm{Na}^{+}$ concentrations. The dependences obtained by Rizzo \& Schellman ( $\square$, [12]), Porschke $(\bigcirc,[14])$, Kam et al. $(\diamond,[11])$ and Baumann et al. $(\bullet,[15])$, are close, more or less, to this curve (the data in [14] and [15] are obtained at low and moderate salt concentrations, $\left.\mathrm{Na}^{+}<0.6 \mathrm{M}\right)$. Only the dependences presented by Sobel \& Harpst $(\boldsymbol{\square},[13])$ and Manning $(\triangle$, $[16])$ and Post $(\nabla,[17])$ corrections to Borochov et al. data [18] (but not Kam et al. corrections, $\diamond,[11])$ greatly differ in shape from Savelyev's dependence [10].

Savelyev [10] demonstrated that the experimental data on the dependence of DNA persistence length on salt concentration are not in satisfactory agreement with the predictions from Odijk [25], Skolnick \& Fixman [26] (OSF) and Manning [27] theories over a wide range of salt concentrations. According to the OSF theory $[25,26], P$ roughly does not depend on monovalent cations concentration after $\sim 0.05 \mathrm{M}$. This theory is in agreement with the experimental data only in a very narrow range of $\mathrm{Na}^{+}$concentrations (about $100 \mathrm{mM}$ ). The Manning theory is in a good agreement with the experimental data only at salt concentration above $100 \mathrm{mM} \mathrm{Na}^{+}$. Later Fixman [28] and Le Bret [29] independently calculated the electrostatic contribution to the DNA persistence length on the basis of Poisson-Boltzmann equation and obtained similar results. These results are still not in good agreement with the experimental data [29], however, the dependence of the persistence length on salt concentration calculated by these authors resembles (at least qualitatively) the results of the molecular dynamic simulations [10] presented in Fig. 1. The controversy among both theoretical and experimental predictions centered on the role of electrostatic and non-electrostatic interactions in regulation of DNA stiffness [9, 10]. By means of molecular dynamic simulations, Savelyev et al. [30] found that electrostatic and non-electrostatic effects play a comparable role in maintaining the DNA rigidity. To understand the relationship among base stacking, electrostatic effects, functional group occupancy of the DNA grooves, and DNA mechanical properties, Peters et al. [31, 32] have created double-helical DNA variants replacing normal bases with various cationic, anionic or neutral analogs and applied different techniques to measure the bending flexibility 
of these polymers. The $P$ values of these DNA variants were within the range of values reported for sequence-dependent variation of the natural DNA bases. The authors demonstrated that the main effect of the base modifications was their ability to drive transitions to helical conformations different from the canonical B-form DNA. They noted that the feature(s) of structurally polymorphic forms, which are responsible for their distinct mechanical properties, remain unclear. Thus experimental and computational studies show that the fundamental origins of the remarkable stiffness of double-stranded DNA are still not understood well and a conceptually new understanding needs to be developed [10, 32, 33].

The inadequacy of theoretical description of dependence of the DNA persistence length on salt concentration over a wide range of cation concentrations may be due in part to the absence of the accurate and predictive models of the ion atmosphere around nucleic acids and their electrostatics [34]. To screen a high negative charge, the bare nucleic acids induce a condensation of cations from the bulk solution [35] forming the major part of the ion atmosphere surrounding them. This condensed layer effectively neutralizes $\sim 70 \%$ of DNA backbone charge. The ion atmosphere, which is an integral part of nucleic acid is highly mobile, involves many ions that can occupy different positions with respect to the nucleic acid and each other, and varies with ionic conditions [34]. Concentration of cations in the ion atmosphere is higher, and that of anions is lower than in the bulk solution. The ion atmosphere extends until the ion concentrations become equal to the bulk ion concentration (tens of angstroms depending on condi- tions). The total combined charge of the ion atmosphere is equal and opposite to that of the nucleic acid.

Lipfert et al. [34] noted that the commonly used theoretical descriptions of the ion atmosphere (counterion condensation theory of Manning, Poisson-Boltzman theory, molecular dynamic (MD) approach and others) have limitations and do not quantitatively account for all aspects of the nucleic acid-ion interaction. In particular, Savelyev \& MacKerell [36-38] have demonstrated the importance of the inclusion of explicit polarization effects in the force fields. Only utilizing a polarizable force field in their MD simulations, the authors revealed a differential impact of the monovalent ions $\mathrm{Li}^{+}, \mathrm{Na}^{+}, \mathrm{K}^{+}$, and $\mathrm{Rb}^{+}$on the DNA conformational properties. According to Savelyev \& MacKerell [38], the primary microscopic mechanism explaining the phenomenon is the formation of the water-mediated hydrogen bonds (H-bonds) between solvated cations located inside the minor groove and simultaneously to two DNA strands. Intensity of this process depends on both the type of ion and the DNA sequence. Such H-bond formation appreciably shifts BI/BII backbone conformational equilibrium towards the BII population.

Unlike DNA persistence length, dependences of DNA effective diameter on salt concentration (Fig. 1B) are in remarkably good agreement with theoretical predictions based on polyelectrolyte theory [2]. According to Rubenkov et al. [7] such agreement shows that polyelectrolyte theory describes well longdistance interactions between the DNA segments, which are the chief contributions to the value of DNA effective diameter [19]. The 
comparison of dependences of DNA persistence length and effective diameter on salt concentration (Figures 1A and 1B) shows that they have a different character. The $d_{e f}$ decreases in a smooth manner with increasing salt concentration, whereas there is, possibly, plateau-like region in the middle part of the $P$ dependence. In particular, under increasing $\mathrm{Na}^{+}$concentration from $10 \mathrm{mM}$ to $100 \mathrm{mM}$, the value of $d_{e f}$ decreases 2.7-3.2 times, whereas $P$ decreases only 1.1-1.4 times (Fig. 1). This means that the impact of ionic conditions on the DNA conformational properties in the cation range of approximately $10-200 \mathrm{mM}$, is characterized mainly by the $d_{e f}$ dependence on salt concentration.

\section{Impact of different factors on DNA persistence length}

The large scattering of the experimental points in Fig. 1A may be caused by different theoretical interpretation of the experimental data and other reasons. In particular, the symbols $\diamond, \triangle$ and $\nabla$ in Fig. 1 A refer to the Borochov et al. data [18] on light scattering of Col E1 DNA, corrected on the basis of excludedvolume theory according to Kam et al [11], Manning [16] and Post [17], respectively. At low salt concentrations, the data $(\diamond)$ of Kam et al. [11] diverge from those of Manning [16] $(\triangle)$ and Post $[17](\nabla)$. The symbols $\mathbf{\square}$ and $\square$ refer to the same DNA (T7 bacteriophage DNA) studied by the methods of Rayleigh light scattering [13] and flow dichroism [12], respectively. In this case the dependencies are also most distinguishable at low salt concentrations. Besides, they have different characters; the second curve seems to reach a plateau at $\mathrm{Na}^{+}$concentration above $0.01 \mathrm{M}$.
The remarkably large scattering of the points at low salt concentrations may be explained by the contribution of buffer solutions. Since $\mathrm{NaCl}$ was used for varying salt concentration in all studies presented in Fig. $1 \mathrm{~A}, \mathrm{Na}^{+}$ and $\mathrm{Cl}^{-}$were predominant ions at modest or high ionic strengths. However in the experimental studies, DNA samples were dissolved in buffer solutions, which contained $\mathrm{Na}_{2}$ EDTA (0.1-2 $\mathrm{mM})$ and either sodium phosphate buffer (total $\mathrm{Na}^{+} 2-5 \mathrm{mM}$ ) [11-13] or $1 \mathrm{mM}$ sodium cacodylate buffer $[14,15]$. Thus, the contribution of buffers anions (including divalent anions EDTA-2 and $\mathrm{HPO}_{4}^{-2}$ ) to DNA solutions was comparable with that of $\mathrm{Cl}^{-}$in a low salt concentration range.

Gebala et al. [39, 40] first studied in details how anion exclusion contributes to the overall ion atmosphere formation around DNA. They revealed by ion counting technique that the extent of monovalent anion exclusion and monovalent cation inclusion significantly depends on both the identity of the anion and that of accompanying cation. The differences were prominent only at high salt concentrations and arose from non-ideal behavior of simple electrolytes. Nevertheless, we suppose that in the experiments presented in Fig. 1A, anions could impact on the DNA ionic atmosphere and persistence length at low salt concentrations since the solutions contained cation of single identity $\left(\mathrm{Na}^{+}\right)$and (in comparable concentrations) combinations of anions of different identity and valency.

The large scattering of the points at low salt concentrations may be also due to small contaminations of multivalent cations in monovalent salt solutions. As mentioned above, EDTA (0.1-2.0 $\mathrm{MM})$ was used to trap 
such contaminations in all experimental studies presented in Fig. 1A, but its level could be not sufficiently high in some studies. Monovalent and multivalent counterions have quite different effects on DNA stiffness. In particular Baumann et al. [15] determined, with the use of a force-measuring laser tweezers apparatus, that the persistence length of $\lambda$-bacteriophage DNA is $86-96 \mathrm{~nm}$ in monovalent salt solutions at $\sim 1.86 \mathrm{mM} \mathrm{Na}^{+}$. Addition of $100 \mu \mathrm{M} \mathrm{Mg}^{2+}$ or $25 \mu \mathrm{M} \mathrm{Co}\left(\mathrm{NH}_{3}\right)_{6}{ }^{3+}$ leads to $P$ values as low as $41-51 \mathrm{~nm}$ and $18-30 \mathrm{~nm}$, respectively.

The sequence dependence of DNA persistence length also may contribute to the scattering of the points in Fig 1A. Geggier and Vologodskii [41] showed that, with a good accuracy, the sequence dependence of DNA bending rigidity is specified by the properties of the dinucleotide steps. The authors determined that the values of persistence length span from $41.7 \mathrm{~nm}$ for CC/GG step to $55.3 \mathrm{~nm}$ for the combination of $\mathrm{AC} / \mathrm{GT}, \mathrm{CG}$ and $\mathrm{GA} /$ TC steps. According to their data, the persistence length of the "average" DNA molecule with equal fraction of each nucleotide is $48.5 \mathrm{~nm}$, which is in good agreement with many other studies. However the authors note that the dinucleotide approximation does not work well for the DNA molecules containing fragments with special structural properties, in particular, GGGCCC motifs and/or A-tracts.

G-tracts favor the A-DNA helix conformation [42-47]. While GGGCCC in DNA duplex CATGGGCCCATG crystallizes in an intermediate A/B conformation, duplex AGGGGCCCCT, which contains a longer G-tract, crystallizes in a global conformation resembling that of a canonical A-form
DNA $[42,43]$. In solution, the structure of the first duplex is a slightly modified B-DNA [44]. Study of several DNA duplexes with G-tracts (including the second duplex) in solution by Fourier transform IR and CD spectroscopy [45] showed that all of them are in a dominating B-DNA conformation, however certain spectral variations suggest a predisposition for the A-type conformation depending of the length of the G-tract and the sequence context. Study of the aqueous duplex GGGGCCCC and its sequence isomer CCCCGGGG by $\mathrm{CD}$ and NMR spectroscopy $[46,47]$ showed A-like guanine-guanine stacking in both duplexes, whereas the cytosine bases stack in a B-like fashion in the duplex GGGGCCCC but in an A-like fashion in the duplex CCCCGGGG. The propensity of G-tracts for the A $\leftrightarrow$ B helical transition provides a possible mode for regulating protein-DNA interactions [42].

A-tracts (runs of four or more $\mathrm{A} \bullet \mathrm{T}$ base pairs) cooperatively form a double helix in the B-DNA family of secondary structures [48]. The base pairs in these tracts are propeller twisted permitting the formation of bifurcated (three-centered) H-bonds between an adenine base and an adjacent thymine base on the opposite strand of a helix that can improve basestacking interaction. It has been supposed that the cross-strand interaction in this helix is adenine $\mathrm{C} 2 \mathrm{H}-\mathrm{O} 2$ thymine [49-51] rather than adenine N6-O4 thymine, as it was reported in earlier works [48]. The minor groove of A-tracts is narrow. The propeller-twisted conformation is stabilized by the spine of hydration in the minor groove of A-tracts.

A-tracts exhibit a temperature-dependent premelting behavior below the temperature, at which the dissociation into single strands 
occurs (in the range $10{ }^{\circ} \mathrm{C}<\mathrm{t}^{\circ}<70{ }^{\circ} \mathrm{C}$ in a physiological salt solution). This premelting transition is well modeled as a transition between at least two helical states $[48,52]$. The midpoint of the transition is $30-40{ }^{\circ} \mathrm{C}$. It is accompanied by a disruption of bound water and breaking the bifurcated H-bonds. Currently the source of the high stability and rigidity of A-tracts is not completely elucidated, since the spine of hydration is not a stabilizing factor unique for A-tracts and contribution of bifurcated H-bonds to their stability is under discussion [48]. Recently Zubatiuk et al. [53] studied the role of microhydration in a structure of $(\mathrm{dA}: \mathrm{dT})_{5}$ mini-helix by quantum-chemical modeling. The authors suggested that formation of a specific water pattern not only in a minor but also in a major grove is the factor responsible for the stabilization of A-tracts.

A-tracts can cause global helix bending when repeated tandemly with the helical repeat. The curvature of DNA with A-tracts depends, in particular, on temperature, ionic strength of the solution, A-tract length, and the relative number of $\mathrm{A} \cdot \mathrm{T}$ base pairs in the A-tracts flanking sequences $[54,55]$. A-tracts are involved in a variety of functions in vivo, for example in transcription regulation, DNA replications and recombination [48]. However, the biological importance of A-tracts may often be determined by their unique structure rather than the global curvature that they induce [48].

\section{Conclusion}

Thus, the large scattering of the points in the dependence of the DNA persistence length on $\mathrm{Na}^{+}$concentration (Fig. 1A) may be due to the presence of sequence blocks in DNA with conformations distinct from the canonical B-form, different theoretical interpretation of the experimental data, buffer components (at low ionic strength) and the presence of contaminations of multivalent cations in DNA solutions.

Further experimental and theoretical studies on DNA persistence length are required for identifying fundamental forces responsible for DNA stiffness to better understand the mechanisms of DNA packaging, replication, recombination and other biological processes. It is also important for the engineering of nanostructures built from double-stranded DNA and creating vectors for the drugs delivery.

\section{Acknowledgements}

The authors are grateful to Prof. A. V. Sivolob and Prof. L. G. Gorb for useful discussion.

\section{REFERENCES}

1. Sharp KA, Honig B. Salt effects on nucleic acids. Curr Opin Struct Biol. 1995;5(3):323-28.

2. Vologodskii A, Cozzarelli N. Modeling of long-range electrostatic interactions in DNA. Biopolymers. 1995;35(3):289-96.

3. Shaw SY, Wang JC. Knotting of a DNA chain during ring closure. Science. 1993;260(5107):533-6.

4. Brian AA, Frisch HL, Lerman LS. Thermodynamics and equilibrium sedimentation analysis of the close approach of DNA molecules and a molecular ordering transition. Biopolymers. 1981;20(6):1305-28.

5. Yarmola EG, Zarudnaya MI, Lazurkin YuS. Osmotic pressure of DNA solutions and effective diameter of the double helix. J Biomol Struct Dyn. 1985;2(5):981-93.

6. Nicolai T, Mandel M. Ionic strength dependence of the second virial coefficient of low molar mass DNA fragments in aqueous solutions. Macromolecules. 1989; 22(1):438-44. 
7. Rybenkov VV, Cozzarelli NR, Vologodskii AV. Probability of DNA knotting and the effective diameter of the DNA double helix. Proc Natl Acad Sci USA. 1993; 90(11):5307-11.

8. Hagerman PJ. Flexibility of DNA. Annu Rev Biophys Biophys Chem. 1988;17:265-86.

9. Peters JP, James Maher L III. DNA curvature and flexibility in vitro and in vivo. $Q$ Rev Biophys. 2010;43(1):23-63.

10. Savelyev $A$. Do monovalent mobile ions affect DNA's flexibility at high salt content? Phys Chem Chem Phys. 2012;14(7):2250-4.

11. Kam Z, Borochov N, Eisenberg H. Dependence of laser light scattering of DNA on $\mathrm{NaCl}$ concentration. Biopolymers. 1981;20(12):2671-90.

12. Rizzo V, Schellman J. Flow dichroism of T7 DNA as a function of salt concentration. Biopolymers. 1981;20(10):2143-63.

13. Sobel ES, Harpst JA. Effects of $\mathrm{Na}^{+}$on the persistence length and excluded volume of T7 bacteriophage DNA. Biopolymers. 1991;31(13):1559-64.

14. Porschke D. Persistence length and bending dynamics of DNA from electrooptical measurements at high salt concentrations. Biophys Chem. 1991; 40(2):169-79.

15. Baumann CG, Smith SB, Bloomfield VA, Bustamante $C$. Ionic effects on the elasticity of single DNA molecules. Proc Natl Acad Sci U S A. 1997; 94(12):6185-90.

16. Manning GS. A procedure for extracting persistence lengths from light-scattering data on intermediate molecular weight DNA. Biopolymers. 1981;20(8): 1751-5.

17. Post $C B$. Excluded volume of an intermediatemolecular-weight DNA. A Monte Carlo analysis. Biopolymers. 1983;22(4):1087-96.

18. Borochov N, Eisenberg H, Kam Z. Dependence of DNA conformation on the concentration of salt. Biopolymers. 1981;20(1):231-5.

19. Stigter D. Interactions of highly charged colloidal cylinders with applications to double-stranded DNA. Biopolymers. 1977;16(7):1435-48.

20. Cairney KL, Harrington RE. Flow birefringence of T7 phage DNA: dependence on salt concentration. Biopolymers. 1982;21(5):923-34.
21. Maret $G$, Weill $G$. Magnetic birefringence study of the electrostatic and intrinsic persistence length of DNA. Biopolymers. 1983;22(12):2727-44.

22. Geggier S, Kotlyar A, Vologodskii A. Temperature dependence of DNA persistence length. Nucleic Acids Res. 2011;39(4):1419-26.

23. Savelyev A, Papoian GA. Chemically accurate coarse graining of double-stranded DNA. Proc Natl Acad Sci U S A. 2010;107(47):20340-5.

24. Hagerman PJ. Investigation of the flexibility of DNA using transient electric birefringence. Biopolymers. 1981;20(7):1503-35.

25. Odijk T. Polyelectrolytes near the rod limit. J Polym Sci Polym Phys Ed. 1977;15(3):477-83.

26. Skolnick J, Fixman M. Electrostatic persistence length of a wormlike polyelectrolyte. Macromolecules. 1977;10(5):944-8.

27. Manning GS. The persistence length of DNA is reached from the persistence length of its null isomer through an internal electrostatic stretching force. Biophys J. 2006;91(10):3607-16.

28. Fixman $M$. The flexibility of polyelectrolyte molecules. J Chem Phys. 1982;76(12):6346-53.

29. Le Bret M. Electrostatic contribution to the persistence length of a polyelectrolyte. J Chem Phys. 1982;76(12):6243-55.

30. Savelyev A, Materese CK, Papoian GA. Is DNA's rigidity dominated by electrostatic or nonelectrostatic interactions? J Am Chem Soc. 2011;133(48): 19290-3.

31. Peters JP, Yelgaonkar SP, Srivatsan SG, Tor Y, James Maher L III. Mechanical properties of DNA-like polymers. Nucleic Acids Res. 2013;41(22):10593604.

32. Peters JP, Mogil LS, McCauley MJ, Williams MC, James Maher L III. Mechanical properties of basemodified DNA are not strictly determined by base stacking or electrostatic interactions. Biophys $J$. 2014;107(2):448-59.

33. Kahn JD. DNA, flexibly flexible. Biophys $J$. 2014;107(2):282-4.

34. Lipfert J, Doniach S, Das R, Herschlag D. Understanding nucleic acid-ion interactions. Annu Rev Biochem. 2014;83:813-41. 
35. Manning GS. The molecular theory of polyelectrolyte solutions with applications to the electrostatic properties of polynucleotides. $Q$ Rev Biophys. 1978;11(2):179-246.

36. Savelyev A, MacKerell AD Jr. Differential impact of the monovalent ions $\mathrm{Li}^{+}, \mathrm{Na}^{+}, \mathrm{K}^{+}$, and $\mathrm{Rb}^{+}$on DNA conformational properties. $J$ Phys Chem Lett. 2015; 6(1):212-6.

37. Savelyev A, MacKerell AD Jr. Competition among $\mathrm{Li}^{+}, \mathrm{Na}^{+}, \mathrm{K}^{+}$, and $\mathrm{Rb}^{+}$monovalent ions for DNA in molecular dynamics simulations using the additive CHARMM36 and Drude polarizable force fields. $J$ Phys Chem B. 2015;119(12):4428-40.

38. Savelyev A, MacKerell AD Jr. Differential deformability of the DNA minor groove and altered BI/BII backbone conformational equilibrium by the monovalent ions $\mathrm{Li}^{+}, \mathrm{Na}^{+}, \mathrm{K}^{+}$, and $\mathrm{Rb}^{+}$via water-mediated hydrogen bonding. $J$ Chem Theory Comput. 2015;11(9):4473-85.

39. Gebala M, Giambaşu GM, Lipfert J, Bisaria N, Bonilla $S$, Li G, York DM, Herschlag D. Cationanion interactions within the nucleic acid ion atmosphere revealed by ion counting. J Am Chem Soc. 2015;137(46):14705-15.

40. Gebala M, Bonilla S, Bisaria N, Herschlag D. Does cation size affect occupancy and electrostatic screening of the nucleic acid ion atmosphere? J Am Chem Soc. 2016;138(34):10925-34.

41. Geggier S, Vologodskii A. Sequence dependence of DNA bending rigidity. Proc Natl Acad Sci U S A. 2010;107(35):15421-26.

42. Ng H-L, Dickerson RE. Mediation of the A/B-DNA helix transition by G-tracts in the crystal structure of duplex CATGGGCCCATG. Nucleic Acids Res. 2002;30(18):4061-7.

43. Gao $Y G$, Robinson $H$, Wang $A H$. High-resolution A-DNA crystal structures of d(AGGGGCCCCT). An A-DNA model of poly(dG) x poly(dC). Eur J Biochem. 1999;261(2):413-20.

44. Dornberger U, Spacková N, Walter A, Gollmick FA, Sponer J, Fritzsche H. Solution structure of the dodecamer d-(CATGGGCCCATG)2 is B-DNA. Experimental and molecular dynamics study. J Biomol Struct Dyn. 2001;19(1):159-74.
45. Lindqvist M, Gräslund A. An FTIR and CD study of the structural effects of G-tract length and sequence context on DNA conformation in solution. $J$ Mol Biol. 2001; 314(3):423-32.

46. Trantírek L, Štefl R, Vorličková M, Koča J, Sklenár V, $K y p r J$. An $A$-type double helix of DNA having $B$ type puckering of the deoxyribose rings. $J$ Mol Biol. 2000; 297(4):907-22.

47. Štefl R, Trantírek L, Vorličková M, Koča J, Sklenár V, Kypr J. A-like guanine-guanine stacking in the aqueous DNA duplex of d(GGGGCCCC). J Mol Biol. 2001;307(2):513-24.

48. Haran TE, Mohanty $U$. The unique structure of Atracts and intrinsic DNA bending. $Q$ Rev Biophys. 2009;42(1):41-81.

49. Hovorun DM. On the microstructural origin of the linear DNA curvature. Dopov Nac acad nauk Ukr. 1998;5:189-95.

50. Ghosh A, Bansal M. C-H.O hydrogen bonds in minor groove of A-tracts in DNA double helices. $J$ Mol Biol. 1999;294(5):1149-58.

51. Munksgaard Nielsen L, Holm AI, Varsano D, Kadhane U, Hoffmann SV, Di Felice R, Rubio A, Brøndsted Nielsen $S$. Fingerprints of bonding motifs in DNA duplexes of adenine and thymine revealed from circular dichroism: synchrotron radiation experiments and TDDFT calculations. $J$ Phys Chem B. 2009;113(28):9614-9.

52. Premilat $S$, Albiser $G$. X-ray fibre diffraction study of an elevated temperature structure of poly(dA)·poly(dT). J Mol Biol. 1997;274(1):6471.

53. Zubatiuk T, Shishkin O, Gorb L, Hovorun D, Leszczynski $J$. Structural waters in the minor and major grooves of DNA - a major factor governing structural adjustments of the A-T mini-helix. $J$ Phys Chem B. 2015;119(2):381-91.

54. Stellwagen E, Peters JP, James Maher L III, Stellwagen NC. DNA A-tracts are not curved in solutions containing high concentrations of monovalent cations. Biochemistry. 2013;52(24):4138-48.

55. Stellwagen E, Dong Q, Stellwagen NC. Flanking A $\bullet$ T basepairs destabilize the $\mathrm{B}^{*}$ conformation of DNA A-tracts. Biophys J. 2015;108(9):2291-9. 


\section{Залежність персистентної довжини ДНК від іонних умов}

М. І. Зарудна, А. Л. Потягайло, Д. М. Говорун

Функціонування ДНК включає як значне стиснення при утворенні хроматину або пакуванні у вірусні частинки, так і утворення петель при контролі генної експресії. Персистентна довжина $(P)$, що характеризує жорсткість дволанцюгової ДНК на вигинання, має безпосереднє відношення до цих процесів. Незважаючи на численні експериментальні та теоретичні дослідження персистентної довжини, загальна думка про характер її залежності від концентрації солі нині так і не визріла - немає чіткого розуміння природи фундаментальних сил, які обумовлюють жорсткість ДНК. В даному короткому огляді ми наводимо на основі літературних даних узагальнену залежність персистентної довжини ДНК від концентрації солі і обговорюємо вплив на неї різних факторів. Зокрема, ми обговорюємо структурні особливості G- та А-трактів ДНК.

Кл юч о в і с л о в а: ДНК, персистентна довжина, ефективний діаметр, G-тракти, А-тракти

\section{Зависимость персистентной длины ДНК от ионных условий}

М. И. Зарудная, А. Л. Потягайло, Д. Н. Говорун

Функционирование ДНК включает как значительное сжатие при образовании хроматина или упаковке в вирусные частицы, так и образование петель при контроле генной экспрессии. Персистентная длина $(P)$, характеризующая жесткость двухцепочечной ДНК на изгиб, имеет непосредственное отношение к этим процессам. Несмотря на многочисленные экспериментальные и теоретические исследования персистентной длины, общее мнение о характере ее зависимости от концентрации соли в настоящее время не установлено и нет ясного понимания природы фундаментальных сил, обуславливающих жесткость ДНК. В данном коротком обзоре мы приводим на основании литературных данных обобщенную зависимость персистентной длины ДНК от концентрации соли и обсуждаем влияние на нее разных факторов. В частности, мы обсуждаем структурные особенности G- и А-трактов ДНК.

Кл юч е в ы е с ов а: ДНК, персистентная длина, эффективный диаметр, G-тракты, А-тракты

Received 15.02.2017 